\title{
Comparative analysis of analytical and experimental results of the strength of compressed reinforced concrete columns under special combinations of loads
}

\author{
Ashot Tamrazyan ${ }^{l}$, and Levon Avetisyan ${ }^{l, *}$ \\ ${ }^{1}$ Moscow State University of Civil Engineering, Department of Reinforced Concrete and Masonry \\ Structures, 26 Yaroslavskoye Shosse, Moscow, 129337, Russia
}

\begin{abstract}
The article presents a comparison of results of experimental and analytical calculations of the strength of the central and eccentrically compressed concrete elements working in the conditions of dynamic loads under fire exposure. The diagram shows a coefficient of dynamic strength depending on the dynamic loading under high temperature obtained by experimentation way. It is shown, that accounting the dynamic effects in fire condition reduces the load carrying capacity of columns by $40 \%$. Therefore, it is recommended to check the possibility of progressive collapse of buildings and, results of which, appearing the character of dynamic loads on the structure, in calculating load carrying capacity of the structure in fire testing.
\end{abstract}

\section{Introduction}

Using the concept of a dynamic analysis of structures for fire resistance makes it possible to precise the valuation of resistance of buildings to the progressive collapse, survivability.

In [1], it is presented a calculation of the fire resistance of the pylon of the 1st floor of 59 -storey residential buildings in standard fire condition. Loss of the load carrying capacity of the carrier element in fire impacts is determined by the formula.

$$
\begin{gathered}
N_{2} \leq N_{I}(1) \\
N_{1}=\varphi\left(\gamma_{b t} R_{b n} A_{b}+\gamma_{s t} R_{s n} A_{s}\right),
\end{gathered}
$$

$N_{1}$-Load carrying capacity of pilon, $N_{2}$ - acting load on the pylon.

As experimental studies devoted to the dynamic work of reinforced concrete elements operating in different temperature conditions were absent [2,3], the following experimental studies were performed by the authors.

Reinforced concrete specimens were prepared and tested both under central compression and at different eccentricities: $3 \mathrm{~cm}, 3.5 \mathrm{~cm}, 4.0 \mathrm{~cm}$. Experimentally the values

\footnotetext{
${ }^{*}$ Corresponding author: avetisyanlevon@inbox.ru
} 
of the strength of the elements came after the static and dynamic tests at different eccentricities, taking into account the change of the loading speeds.

For obtaining the values of the dynamic strength of compressed reinforced concrete elements in different temperature conditions at different speeds of dynamic impact, the experimental researches were carried out by sample loading rate $-1 \mathrm{sec}$ and 0.4 seconds. In normal conditions all previously known results were confirmed. After receiving all the results in normal conditions the samples were divided by series and heated to $\mathrm{T}=300^{\circ} \mathrm{C}$, $500^{\circ} \mathrm{C}, 700^{\circ} \mathrm{C}, 900^{\circ} \mathrm{C}$ in the test center "TPB TEST" with the plant (Oven Inv. No. 002) for fire tests of small samples of beam structures, according to the standard temperature regime ISO 834.

In order to identify the impact of high temperatures on the properties of concrete under static and dynamic loadings concrete cubes and prisms were tested in different time of load at different temperatures of fire.

Coefficient of dynamic strength of concrete is defined as the ratio of the dynamic to the static strength of concrete $K_{b, d}=R_{d} / R_{s t}$. Coefficient of dynamic strength is a dimensionless relative value and allows the best way to characterize the comparative influence of various factors on the dynamic strength of concrete.

It was revealed that the dynamic hardening coefficient was reduced to $K_{b, d}=0.441$.

Coefficient of dynamic strength is less than unity, because the thermal effects on concrete and reinforced concrete structures are considerably stronger, than the change of speed of application load. The graph of experimental curves (Figure 1) $K_{b, d}$ depending on the heating temperature is found.

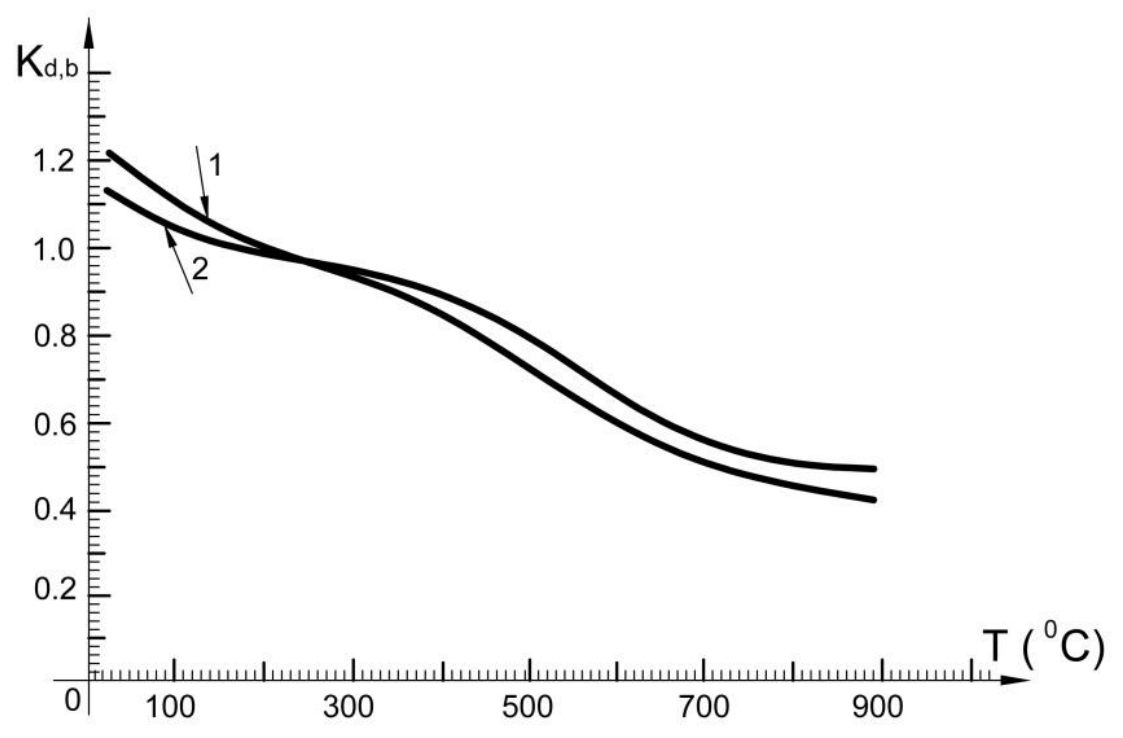

Fig. 1. Dependence $K_{b, d}$ on temperature 1) at the loading time $\mathrm{t}=0.4 \mathrm{sec}$ and 2) at the loading time $\mathrm{t}$ $=1.0 \mathrm{sec}$

The following experiments were carried out to study the changes of physical and mechanical properties of reinforced concrete columns after the temperature exposure [4] and to identify the value of the coefficient of dynamic strength after fire exposure in a single dynamic loading with different eccentricities at different speeds (Figure 2,3). 


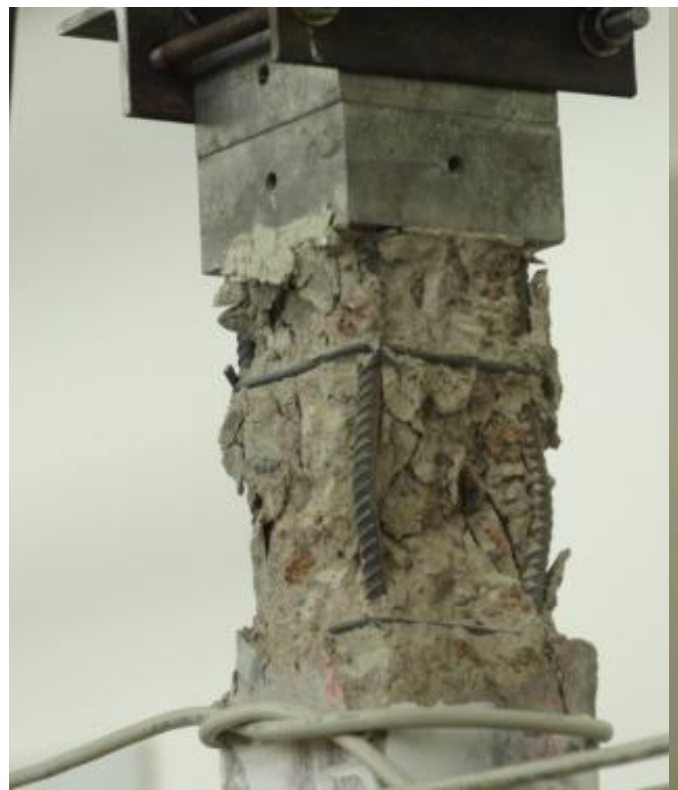

Fig. 2. Central compression (after heating up $900^{\circ} \mathrm{C}$ )

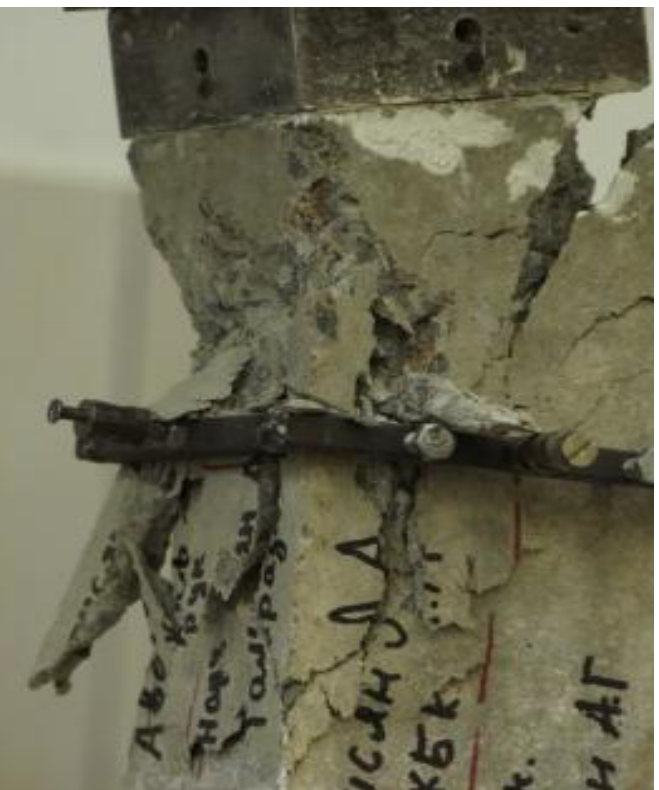

Fig. 3. Eccentric compression, eccentricity $e_{0}=3.5 \mathrm{~cm}$

As a result of experimental research the following results of strength of reinforced concrete columns (Table 1;2) were found.

Table 1. Strength of reinforced concrete columns under static loading, with different eccentricities after different temperature influences

\begin{tabular}{|c|c|c|c|c|}
\hline$T\left({ }^{\circ} \mathrm{C}\right)$ & $\begin{array}{c}\text { Static central } \\
\text { loading }(\mathrm{kN}), \\
e=0.00\end{array}$ & $\begin{array}{c}\text { Static } \\
\text { eccentrically } \\
\text { loading }(\mathrm{kN}), \\
e=3.00 \mathrm{~cm}\end{array}$ & $\begin{array}{c}\text { Static eccentrically } \\
\text { loading }(\mathrm{kN}), \\
e=3.5 \mathrm{~cm}\end{array}$ & $\begin{array}{c}\text { Static } \\
\text { eccentrically } \\
\text { loading }(\mathrm{kN}), \\
e_{0}=4.0 \mathrm{~cm}\end{array}$ \\
\hline $20^{\circ} \mathrm{C}$ & 396.60 & 278.30 & 205.40 & 129.60 \\
\hline $300^{\circ} \mathrm{C}$ & 356.44 & 244.90 & 182.50 & 116.80 \\
\hline $500^{\circ} \mathrm{C}$ & 317.00 & 221.50 & 163.60 & 103.00 \\
\hline $700^{\circ} \mathrm{C}$ & 249.80 & 183.80 & 131.70 & 81.10 \\
\hline $900^{\circ} \mathrm{C}$ & 183.00 & 128.25 & 96.80 & 61.20 \\
\hline
\end{tabular}

Table 2. Results of the strength of reinforced concrete columns at different speeds of dynamic loading with different eccentricities after different temperature influences

\begin{tabular}{|c|c|c|c|c|c|c|c|c|}
\hline$T\left({ }^{0} \mathrm{C}\right)$ & $\begin{array}{c}\text { Dynamic } \\
\text { loading } \\
\text { central } \\
\text { loading } \\
(\mathrm{kN}), \\
\mathrm{t}=1.0 \mathrm{sec}\end{array}$ & $\begin{array}{c}\text { Dynamic } \\
\text { loading } \\
\text { central } \\
\text { loading } \\
(\mathrm{kN}), \\
\mathrm{t}=0.4 \mathrm{sec}\end{array}$ & $\begin{array}{c}\text { Dynamic } \\
\text { ecc. } \\
\text { loading } \\
(\mathrm{kN}), \\
\mathrm{e}=3.0 \mathrm{~cm}, \\
\mathrm{t}=1.0 \mathrm{sec}\end{array}$ & $\begin{array}{c}\text { Dynamic } \\
\text { ecc. } \\
\text { loading } \\
(\mathrm{kN}), \\
\mathrm{e}=3.0 \mathrm{~cm}, \\
\mathrm{t}=0.4 \mathrm{sec}\end{array}$ & $\begin{array}{c}\text { Dynamic } \\
\text { ecc. } \\
\text { loading } \\
(\mathrm{kN}), \\
\mathrm{e}=3.5 \mathrm{~cm}, \\
\mathrm{t}=1.0 \mathrm{sec}\end{array}$ & $\begin{array}{c}\text { Dynamic } \\
\text { ecc. } \\
\text { loading } \\
(\mathrm{kN}), \\
\mathrm{e}=3.5 \mathrm{~cm}, \\
\mathrm{t}=0.4 \mathrm{sec}\end{array}$ & $\begin{array}{c}\text { Dynamic } \\
\text { ecc. } \\
\text { loading } \\
(\mathrm{kN}), \\
\mathrm{e}=4.0 \mathrm{~cm}, \\
\mathrm{t}=1.0 \mathrm{sec} \text {. }\end{array}$ & $\begin{array}{c}\text { Dynamic } \\
\text { ecc. } \\
\text { loading } \\
(\mathrm{kN}), \\
\mathrm{e}=4.0 \mathrm{~cm} \text {, } \\
\mathrm{t}=0.4 \\
\text { sec. }\end{array}$ \\
\hline $20^{\circ} \mathrm{C}$ & 441.68 & 452.40 & 315.60 & 322.40 & 237.50 & 238.15 & 150.2 & 152.66 \\
\hline
\end{tabular}




\begin{tabular}{|c|c|c|c|c|c|c|c|c|}
\hline $300^{\circ} \mathrm{C}$ & 404.74 & 405.10 & 274.50 & 260.80 & 212.66 & 202.33 & 133.0 & 126.30 \\
\hline $500^{\circ} \mathrm{C}$ & 367.94 & 370.50 & 237.90 & 214.10 & 178.00 & 161.20 & 103.9 & 88.74 \\
\hline $700^{\circ} \mathrm{C}$ & 287.88 & 285.70 & 198.70 & 169.55 & 142.00 & 122.90 & 82.50 & 67.95 \\
\hline $900^{\circ} \mathrm{C}$ & 216.00 & 210.72 & 132.60 & 113.47 & 106.87 & 84.89 & 60.48 & 47.28 \\
\hline & \multicolumn{2}{|c|}{$\begin{array}{c}\text { Average deviation } \\
2.45 \%\end{array}$} & \multicolumn{2}{c|}{$\begin{array}{c}\text { Average deviation } \\
14.45 \%\end{array}$} & $\begin{array}{c}\text { Average deviation } \\
20.5 \%\end{array}$ & $\begin{array}{c}\text { Average deviation } \\
21.8 \%\end{array}$ \\
\hline
\end{tabular}

Experimentally, the values of the coefficient of dynamic strength at different eccentricities and at different speeds of dynamic loading came after fire exposure (Table 3).

Table 3. The values of coefficient of dynamic strength $K_{d, T}$ at different speeds of dynamic loading with different eccentricities

\begin{tabular}{|c|c|c|c|c|c|c|c|c|}
\hline $\mathrm{T}\left({ }^{\circ} \mathrm{C}\right)$ & $\begin{array}{c}\mathrm{e}=0.0 \mathrm{~cm}, \\
\mathrm{t}=1.0 \mathrm{sec}\end{array}$ & $\begin{array}{c}\mathrm{e}=0.0 \mathrm{~cm}, \\
\mathrm{t}=0.4 \mathrm{sec}\end{array}$ & $\begin{array}{c}\mathrm{e}=3.0 \mathrm{~cm}, \\
\mathrm{t}=1.0 \mathrm{sec}\end{array}$ & $\begin{array}{c}\mathrm{e}=3.0 \mathrm{~cm}, \\
\mathrm{t}=0.4 \mathrm{sec} \\
\mathrm{e}=3.5 \mathrm{~cm}, \\
\mathrm{t}=1.0 \mathrm{sec}\end{array}$ & $\begin{array}{c}\mathrm{e}=3.5 \mathrm{~cm}, \\
\mathrm{t}=0.4 \mathrm{sec}\end{array}$ & $\begin{array}{c}\mathrm{e}=4.0 \mathrm{~cm}, \\
\mathrm{t}=1.0 \mathrm{sec} .\end{array}$ & $\begin{array}{c}\mathrm{e}=4.0 \mathrm{~cm}, \\
\mathrm{t}=0.4 \\
\mathrm{sec} .\end{array}$ \\
\hline 20 & 1.130 & 1.150 & 1.134 & 1.150 & 1.156 & 1.159 & 1.158 & 1.177 \\
\hline 300 & 1.135 & 1.136 & 1.120 & 1.060 & 1.165 & 1.108 & 1.130 & 1.081 \\
\hline 700 & 1.160 & 1.168 & 1.074 & 0.960 & 1.088 & 0.985 & 1.008 & 0.861 \\
\hline 900 & 1.152 & 1.143 & 1.081 & 0.920 & 1.078 & 0.933 & 1.017 & 0.838 \\
\hline
\end{tabular}

According to the results, shown in Table 1.2, it becomes clear that under static loading reduction the strength is up to $54 \%$ (at temperatures $\mathrm{T}=900^{\circ} \mathrm{C}$ ). Almost the same regularity is kept during the experiments at different eccentricities and temperatures. For a single dynamic impact, with different speeds, the situation obviously changes. Coefficient of dynamic strength, when the experiments is performed in normal conditions varies from 1.1 to 1.2 , and the greater the impact speed, the closer $K_{d}$ to 1.2. After fire explosions the coefficient of dynamic strength at the central dynamic loadings over time $1.0 \mathrm{sec}$ shows values closer to unit, and at the loading time $0.4 \mathrm{sec}$ it decreases to 0.95 . With the increase of the eccentricity the coefficient of dynamic strength is reduced to 0.8 . Research of influence of the loading speed after fire explosions at different eccentricities shows that after heating over $500{ }^{\circ} \mathrm{C}$ with increasing of eccentricity the increase of speed of dynamic loading can lead to a reduction of $K_{d, T}$ to $21.8 \%$ (Table 2). This is explained by brittle fracture of reinforcing steel, because after fire influences the load carrying capacity of reinforcing steel is reduced to $80 \%$.

This is due to the increased share of participation of work reinforcement steel in a dynamic deformation of eccentrically compressed elements [5,6,7].

In the calculations of eccentrically compression elements of construction under dynamic loading, the calculations must be carried out not only in the elastic stage, but also in the plastic one. In the calculation of particular elements, it needs to get solution of the problem based on the deformed schemes of structure. This circumstance, together with the accounting of the plastic work of elements, allows to reveal the real work of construction and thereby to reveal the significant reserve of their dynamic deformation, since a large proportion of input external energy is spent on the work of bending element and plastic deformations before construction collapses.

For comparison, we define the load carrying capacity of reinforced concrete specimens 
(columns) under static and dynamic loading in standard fire condition.

Initial data: sizes $600 \times 100 \times 100 \mathrm{~mm}$; concrete class B30; the average density in a dry condition (granite crushed stone) $\rho_{o c}=2485 \mathrm{~kg} / \mathrm{m}^{3}$; gravimetric humidity $w=4.6 \%$; reinforcing steel $4 \varnothing 8 \mathrm{~A} 400$; thickness of the protective layer $a_{0}=12 \mathrm{~mm}$.

Here, the destruction begins from achievement of the yield point of reinforcement steel in a stretched rebar, and ends by crushing the concrete of compression zone during the development of plastic deformations in the stretched reinforcement rebar.

One of the most important tasks of calculation of fire resistance of building structures is determination of the temperature fields for rectangular columns at the quadripartite fire exposure according to fire standard ISO 834

Calculation of temperature fields of reinforced concrete structures for fire resistance is based on the solution of the boundary value problems of non-stationary thermal conductivity of capillary-porous bodies in standard temperature conditions.

As a result of the analytical solution of heat engineering tasks the temperature of reinforcement rebar for specific intervals time of fire has come, and the cross section area of the core bounded computational(critical) temperature (Table 4) has been determined.

Table 4. The results of thermo-technical calculation

\begin{tabular}{|c|c|c|c|c|}
\hline & $15 \mathrm{~min}$ & $30 \mathrm{~min}$ & $40 \mathrm{~min}$ & $50 \mathrm{~min}$ \\
\hline $\begin{array}{c}\text { Reinforcement steel } \\
\left({ }^{\circ} \mathrm{C}\right)\end{array}$ & 342.18 & 736.92 & 790.36 & 825.9 \\
\hline The core area $(\mathrm{mm})$ & 98.2 & 96.0 & 88.1 & 79.0 \\
\hline
\end{tabular}

The graph is found on the basis of the data of analytical calculations and experimental research for the load carrying capacity of reinforced concrete columns with central and eccentric compression, at the different thermo-power loadings (Figure $4 \mathrm{a}, \mathrm{b}$ ).

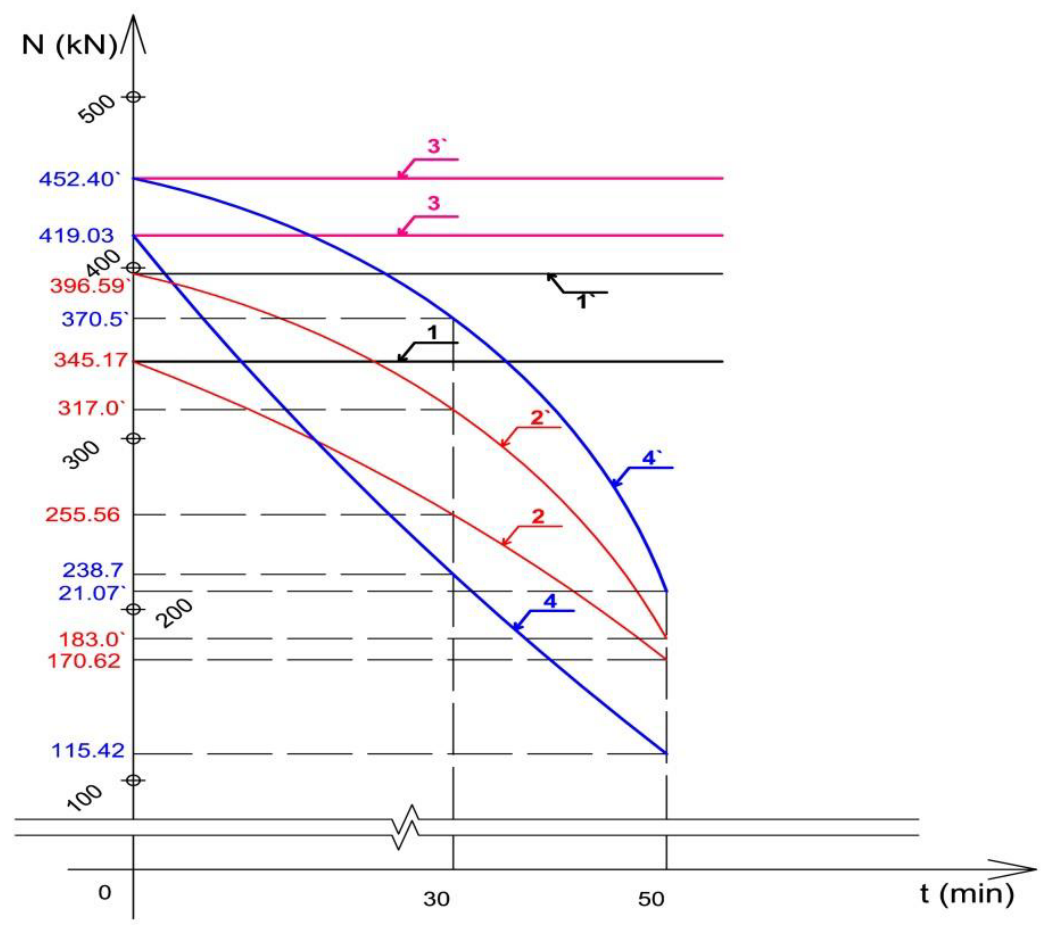

a) Central compression 


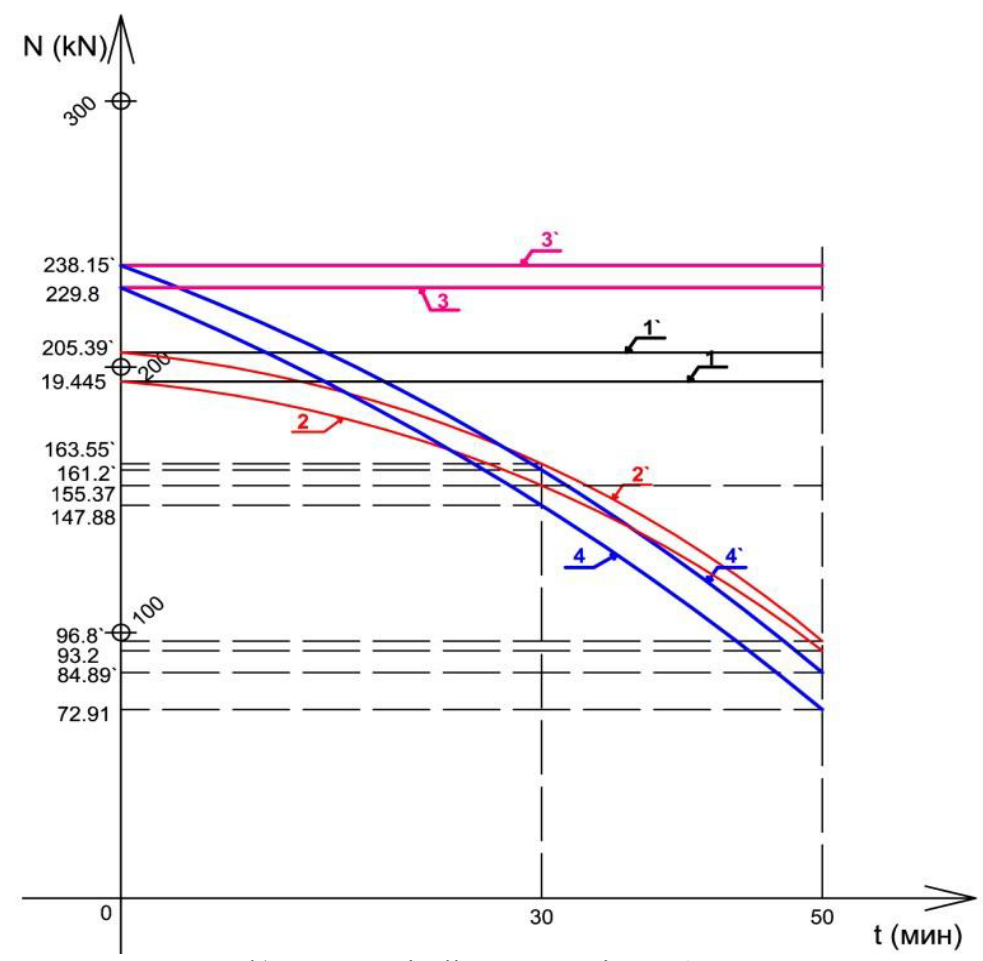

b) Eccentrically compression $\mathrm{e}=3.5 \mathrm{~cm}$.

Fig. 4. Comparison of the analytical and experimental results of the change of the load carrying capacity of reinforced concrete columns under conditions of thermo-dynamic loadings

Calculation results

1. Static loading

2. Static loading in fire condition

3. Dynamic loading

4. Dynamic loading in fire condition
Experimental results

1. Static loading

2. Static loading in fire condition

3. Dynamic loading

4. Dynamic loading in fire condition

\section{Conclusions}

1. Static strength of reinforced concrete columns after fire exposure is reduced to $55 \%$, coefficient of dynamic strength reaches 1.2 depending on the speed of dynamic loading in normal condition. After heating above $500^{\circ} \mathrm{C}$, with increasing of eccentricity the increase of the speed of dynamic loading leads to the reduction of $K_{d, T}$ to $21.8 \%$.

2. The load carrying capacity of eccentrically compressed reinforced concrete columns $(\mathrm{e}=3.5 \mathrm{~cm})$ under static loading in fire condition $\left(900^{\circ} \mathrm{C}\right)$ is reduced by $48 \%$.

3. The load carrying capacity of eccentrically compressed reinforced concrete column $(\mathrm{e}=3.5 \mathrm{~cm})$ under dynamic loading $(\mathrm{t}=0.4 \mathrm{~s})$ in fire impact condition $\left(900^{\circ} \mathrm{C}\right)$ is reduced by $70 \%$.

4. Coefficient of dynamic strength depending on the temperature decreases by linear dependence at: $. \mathrm{T}=300^{\circ} \mathrm{C}-K_{b, d, T}=0.96, \mathrm{~T}=500^{\circ} \mathrm{C}-K_{b, d, T}=0.844, \mathrm{~T}=700^{\circ} \mathrm{C}-K_{b, d, T}=0.59$, $\mathrm{T}=900^{\circ} \mathrm{C}-K_{b, d, T}=0.441$. 


\section{References}

1. A. G. Tamrazyan, ICSMIM 2013, 2nd International conference on sensors, measurement and intelligent materials, 1563-1566 (2013).

2. T.T. Lie, R.J. Irwin, ACI Structural Journal 90 (1), 52-60 (1993).

3. J. Xie, A.E. Elwi, J.G. MacGregor, Structural Journal 93 (4), 449-461 (1996).

4. A.G.Tamrazyan, L.A. Avetisyan, Applied Mechanics and Materials 638-640, 62-65 (2014).

5. T.T. Lie, T.D. Lin, D. E. Allen, M.S. Abrams, National research Council Canada Division of Building research (1984).

6. T. Majevski, J. Bobinski, Engineering Structures 30(2), 300-317 (2008).

7. M. Mohamed Bikhiet, F. El-Shafey Nasser , M. El-Hashimy Hany, Alexandria Engineering Journal 53, 643-653 (2014). 